\title{
Factors influencing a student's decision to pursue a communications degree in Spain
}

\author{
Javier Sierra Sánchez \\ Universitat Abat Oliba CEU (Spain) \\ jsierras@uao.es
}

Received August, 2011

Accepted April, 2012

\section{Abstract}

Purpose: This paper analyzes the factors that influence secondary school students' choice of higher education options in Spain today and explores the implications and benefits of establishing provider-client relationships between universities and students.

Design/methodology/approach: A quantitative approach using questionnaires to demonstrate the hypothesis and achieve the objectives. We have prepared a questionnaire via telematic LimeSurvey application consisting of twenty-four closed questions.

Findings: Results depict that the leading criteria for Spanish students interested in pursuing studies in communication sciences were a university's reputation and excellence and the quality of its educational programmes. In terms of sources of information related to universities and their degree programmes, Spanish communication sciences students placed the highest value on direct and experiential sources. Spanish students interested in pursuing degrees in communication sciences preferred public universities over private universities. 
Research limitations: It is a descriptive paper. The sample could have been larger and have covered the entire universe of communication schools in Spain.

Practical implications: Gain in-depth insight into the academic, cultural, and sociodemographic characteristics of students who choose to pursue an undergraduate degree in communications sciences in Spain.Ascertain which sources of information proved to be the most valuable to prospective students in choosing a university and degree programme and the other factors that influenced their choices by means of a survey involving firstyear undergraduate communication sciences students. Use the results of this survey to rank the criteria used by students when choosing a university and degree programme. Gain a clearer picture of how parents and friends influence a student's choice of degree programmes and universities.

Social implications: Knowing the factors of choice and sources of information that define his choice of the University and the Faculty of Communication Sciences and analyze if there is an adequate marketing specifically university.

Originality/value: Today's universities must operate in much the same manner as businesses and corporations in order to survive. This new scenario pits one university against another in a race to attract the highest number of incoming students.Knowing the preferences of college-age students and the factors that influence their choice of a university has become increasingly crucial for institutions of higher education. This study sets out to determine not only the overall factors that determine a student's choice in Spain, but also specifically what students who have chosen to pursue a university career in communications science look for when deciding where they will earn a degree in that discipline.

Keywords: undergraduate studies, communication science, choice criteria, information sources, university marketing, higher education

Jel Codes: A22, M31 


\section{Introduction}

The Spanish university system continues to undergo a process of change that began with its commitment to the European Higher Education Area (EHEA) framework. The Bologna Plan named after the 1999 declaration that set the mechanics of EHEA in motion, proposed sweeping reforms in higher education throughout Europe, including the implementation of comparable degree programmes in all adherent countries based on a common three-cycle structure of bachelor, masters, and doctorate studies. Designed to promote the mobility of students, graduates, and education professionals throughout Europe, the plan also called for a closer alignment between university studies and the needs of the marketplace and society, more permeable frontiers between the worlds of higher education and industry, and a greater reconciliation between their management styles. This meant that twenty-first century university management in Europe would be based on quality assurance systems, competitiveness, and the optimization of available resources. Numerous reports have been published on this reform process, among the most important, the European Commission's COM reports (2002, 2003), the Spanish Ministry of Education's Estrategia Universidad 2015 (2010), CYD (2009) by Fundación Conocimiento y Desarrollo, and Tendencias Universidad 2020: Estudio de Prospectiva issued by the Office for University Cooperation (OCU).

Concurrent with Spain's implementation of Bologna Plan reforms, its national government ceded greater administrative responsibility for higher education to the governments of its autonomous communities. Universities were granted a higher degree of managerial autonomy in exchange for assuming more responsibility for their economic sustainability. These changes have coincided with a decline in the national birth rate, a rise in the popularity of online degree programmes, and increased competition from a more globalized higher education market. After more than a decade of expansion and diversification of degree programmes, universities are now facing the simultaneous challenges of a decline in public funding, a shrinking pool of college-age prospects and rising expectations regarding the quality and economic value of a university education. As government funding to public universities is pegged to enrolment figures and private universities rely on student enrolment fees to cover the costs of their academic programmes, student enrolment is an increasingly important source of revenue for both. As Veloutsou, Lewis and Paton (2004) note, today's universities must operate in much the same manner as businesses and corporations in order to survive. This new scenario pits one university against another in a race to attract the highest number of incoming 
students Comm and Labay (1996), Landrum, Turrisi and Harless (1998), and Luque and Del Barrio (2007).

Knowing the preferences of college-age students and the factors that influence their choice of a university has become increasingly crucial for institutions of higher education. This study sets out to determine not only the overall factors that determine a student's choice in Spain, but also specifically what students who have chosen to pursue a university career in communications science look for when deciding where they will earn a degree in that discipline.

\section{Selling higher education: relationship and experiential marketing}

There is an abundance of literature related to higher education marketing, beginning with studies carried out in Great Britain and the United States in the 1980s. Other pioneers in the field whose studies serve as references are Davies and Scribbins (1985), Keen and Warner (1989), Seymour and Collett (1991), Baldwin (1994), Aliff (1998), Lust (1998), Shupe (1999), Tierney (1999), Delmonico (2000), and Pitman (2000). Following the Bologna Declaration (1999), Spanish academics began to carry out research that focused on the student as a consumer, the most notable studies being those by Beerli and Díaz (2003), Luque and Del Barrio (2007), and Del Olmo (2009a, 2009b).

Viewed from a marketing perspective, a student's decision as to where to pursue a university career is a purchasing decision and the student is a consumer, although Driscoll and Wicks (1998: page 60) argue that lines should be drawn when applying marketing to higher education, and are quick to point out the inherent dangers of drawing a vender-client analogy between a university and its students. Chapman (1986) was the first to apply the psychology of consumer behaviour to a student's undergraduate or graduate experience, dividing it into three distinct stages: prepurchase evaluation, the purchase process, and post-purchase assessment. Kotler and Fox (1995: page 6) offered the first definition of marketing applied to an educational context, describing it as "the analysis, planning, implementation, and control of carefully formulated programmes designed to bring about voluntary exchanges of value with target markets to achieve institutional objectives."

USA researchers like Soutar and Turner (2002), Maringe (2006), and Holsworth and Nind (2005), conclude in various empirical studies that the most important factors that students take into account when choosing a University and / or training offer (grade / Master's) are: 
- the reputation with employers of the University / faculty / academic offer

- career opportunities

- the graduate employment rate

- the quality of teaching staff

- specific differential aspects (specialisms, timetables, services, etc.)

- cost or value for money.

In this empirical work, we try to test if those factors are the ones that are taken into consideration by Spanish students doing a first degree in Communication Sciences.

"Higher education marketing is fundamentally relationship and experiential marketing", Helgesen (2008). According to Grönroos (1994: page 9), relationship marketing is "a process of identifying and establishing, maintaining, and enhancing relationships with customers and other stakeholders at a profit, so that the objectives of all parties involved are met. This is achieved through a mutual exchange and fulfilment of promises." According to Trullas and Enache (2011: page $8)$, this definition attributes new elements to relationship marketing, such as the concept of creating new value for customers and subsequently sharing it with them and recognition of the key role customers play in the purchasing process and the definition of how the product or service purchasing will further their goals. Of the Grönroos concepts pointed out by Trullas and Enache as being innovative, universities seeking to consolidate their standing and enhance their attractiveness in the eyes of prospective students and faculty members, funders, ranking agencies, and their communities may find his claim that relationship marketing creates value for the customer by building a chain of relationships between organizations and other stakeholders, including providers, distribution channels, and intermediaries, to be the most interesting.

Trullas and Enache (2011: page 15) define marketing for higher education as "a process of investigation devoted to identifying social needs and developing and implementing programmes that fulfil them by means of commercial or noncommercial interchanges for the ultimate purpose of enhancing the wellbeing of the individuals and community involved," adding, "The application of marketing to higher education will create an awareness that the demand is externally generated; programmes will be considered relevant when they satisfy an external need. This 
implies a need for a systematic investigation of the demand and the generation of new products and services designed to satisfy it." For Spanish universities struggling to supplant an out-moded supply-side mentality with an effective demand-side philosophy, relationship marketing may provide a way of getting to know the needs and aspirations of their potential customers better, enhancing the quality and relevance of the educational programmes they offer, and raising the profile of their institutions in a surging tide of competition.

The first step in adapting university recruiting to the realities of a demand-side market is identifying the factors that influence students' decisions about their academic and professional future. According to Soutar and Turner (2002: page 40) factors that influence students' choices include a university's academic reputation, the quality of its teaching, the distance between students' homes and the university campus, and the opinions of friends and family members.

In her masters thesis "Hospitality and Tourism Management in China: the Analysis of Motives and Institution Choice Criteria of HTM Undergraduates," Wei Wei Chen (2009) cites many of the same factors as influencing student choice in China, a coincidence that suggests students worldwide develop similar criteria-information that should be of interest to international recruiters.

These studies show the need for universities and their faculties to develop marketing strategies that create enduring relationships between them and current and prospective students. According to Christopher, Payne and Ballantyne (1991), the objective of relationship marketing is making new clients identify with an organization and transforming them into promoters of their brands and products. Well-planned marketing strategies that foster students' identification with their universities and degree programmes have a double benefit: they not only boost recruitment, but also forge strong emotional ties with students who later go on to become effective promoters of their alma maters.

\section{Hyphotesis}

Drawing upon this theoretical framework, we formulated three hypotheses to be tested during our study.

Hypothesis 1. The leading criteria for Spanish students interested in pursuing studies in communication sciences were the university's reputation and excellence and the quality of its educational programmes. 
Hypothesis 2. In terms of sources of information related to universities and their degree programmes, Spanish communication sciences students placed the highest value on direct and experiential sources.

Hypothesis 3. Spanish students interested in pursuing degrees in communication sciences preferred public universities over private universities.

\section{Research objectives}

We established the following objectives for this study:

- Gain in-depth insight into the academic, cultural, and sociodemographic characteristics of students who choose to pursue an undergraduate degree in communications sciences in Spain.

- Ascertain which sources of information proved to be the most valuable to prospective students in choosing a university and degree programme and the other factors that influenced their choices by means of a survey involving first-year undergraduate communication sciences students.

- Use the results of this survey to rank the criteria used by students when choosing a university and degree programme.

- Gain a clearer picture of how parents and friends influence a student's choice of degree programmes and universities.

\section{Research questions}

Analyzing how students choose a university and degree programme entails understanding a complex process comprised of numerous personal and environmental variables.

For this study, we formulated the following six research questions:

- How do future university students go about choosing between the options available to them?

- What criteria do they use to evaluate these options?

- Where do they search for information concerning these options?

- How do they evaluate the information they have obtained? 
- What factors exert the greatest influence in their decision concerning what they will study and which schools they will apply to?

- How well prepared are they to make a suitable decision concerning a product as complex as a university education?

\section{Methodology}

A thorough review of the related literature was carried out in order to refine the focus of our research and choose the best methods for arriving at valid answers to our research questions. To this end, we consulted the data bases of various digital research platforms such as Web of Knowledge, Scopus, ABI-INFORM, ECONLIT, and Publish or Perish, as well as those of the foremost journals in the fields of marketing and education, including the International Journal of Public Sector Management, Studies in Higher Education, the Journal of Higher Education Policy and Management, the International Journal of Educational Management, the Journal of Marketing for Higher Education, the Journal of Education for Business, and the Journal of Professional Services Marketing.

To obtain the data needed to carry out this study, we used Limesurvey software to formulate an online questionnaire containing twenty-four closed format questions. This questionnaire was distributed to a target population of first-year undergraduate students enrolled in communication sciences programmes at public and private universities in Spain using a nonprobablity sampling method based on quotas that respected the demography of the population. The responses received were processed at Abat Oliba CEU University's data processing centre. SPSS version 18 software was used to handle and extract the data. Of the 46 Spanish universities offering some kind of a communications sciences degree who were contacted, 9 private and 9 public universities and a total of 344 students participated in the survey.

Table 1 provides a breakdown of the sociodemographic characteristics of the sample used for this study. Every possible attempt was made to achieve a balanced distribution of students by geographic origin and between private and public institutions. Of the 344 students who participated in this study, 52.6\% attended public universities and $47.4 \%$ attended private universities (see table 2 ). A genderbalanced sample was not achievable due to the greater enrolment of female students in these study programmes, a statistic confirmed by the Informe Anual de la Profesión Periodística (2010). 


\begin{tabular}{|c|c|r|r|}
\hline Variable & Sub-category & Number & Percentage \\
\hline \multirow{3}{*}{ Type of university } & Public & 181 & $52.6 \%$ \\
\cline { 2 - 4 } & Private & 163 & $47.4 \%$ \\
\hline \multirow{3}{*}{ Gender } & Men & 113 & $32.8 \%$ \\
\hline \multirow{3}{*}{ Degree programme } & Women & 231 & $67.2 \%$ \\
\cline { 2 - 4 } & Jdvertising and Public Relations & 124 & $36.0 \%$ \\
\cline { 2 - 4 } & Audiovisual Communication & 140 & $40.7 \%$ \\
\cline { 2 - 4 } & Other & 59 & $17.2 \%$ \\
\hline \multirow{3}{*}{ Age/year of birth } & 1988 & 6 & $6.1 \%$ \\
\cline { 2 - 4 } & 1989 & 15 & $4.7 \%$ \\
\cline { 2 - 4 } & 1990 & 34 & $9.9 \%$ \\
\cline { 2 - 4 } & 1991 & 198 & $17.7 \%$ \\
\cline { 2 - 4 } & 1992 & 30 & $57.6 \%$ \\
\cline { 2 - 4 } & Other years & $8.7 \%$ \\
\hline
\end{tabular}

Table 1. Sociodemographic characteristics of Sample Population

\begin{tabular}{|c|c|r|r|}
\hline Variable & Sub-category & Number & Percentage \\
\hline \multirow{2}{*}{$\begin{array}{c}\text { Type of secondary } \\
\text { school attended }\end{array}$} & Public school & 177 & $51.5 \%$ \\
\cline { 2 - 4 } & Religiously-affiliated private or charter school & 110 & $32.0 \%$ \\
\cline { 2 - 4 } & Secular private or charter school & 57 & $16.6 \%$ \\
\hline
\end{tabular}

Table 2. Type of secondary school attended by sample population

The majority of survey participants had graduated from public schools $(51.5 \%)$. Students who had attended religiously-affiliated private or charter schools represented $32 \%$ of the sample population. The remainder $(16.6 \%)$ had received their secondary education from non-denominational private or charter schools.

\section{Results: description and analysis}

The majority of students surveyed (86.9\%) had gained admission to a university degree programme on the basis of their university entrance examination scores. The remainder entered via special admission programmes for adult students, professional training programmes, or based on a secondary school diploma earned in a foreign country.

Spanish secondary school students wishing to enter to a university are required to take a general entrance examination (PAU). The score obtained on this exam is combined with their secondary school grade average to arrive at an overall university admissions score. Students taking the PAU have the opportunity to improve their overall admissions scores by taking additional subject-specific entrance exams. The majority of students participating in the survey had taken both rounds of entrance examinations (see table 3 ). 


\begin{tabular}{|c|c|r|r|}
\hline Variable & Sub-category & Number & Percentage \\
\hline \multirow{3}{*}{$\begin{array}{c}\text { University entrance } \\
\text { examinations }\end{array}$} & Took only general examination & 70 & $20.3 \%$ \\
\cline { 2 - 4 } & $\begin{array}{c}\text { Took both the general and optional } \\
\text { subject-specific examinations }\end{array}$ & 229 & $66.6 \%$ \\
\cline { 2 - 4 } & Other & 45 & $13.1 \%$ \\
\hline
\end{tabular}

Table 3. Types of university entrance examinations taken by sample population

According to the Informe Anual de la Profesión Periodística (2010), the cut-off score for admission to a public university communication sciences programme is between 7 and 8 on a scale of 1 to 10 . The breakdown of the general university admissions examination scores obtained by students participating in the survey (see table 4) indicate that the majority of surveyed students had participated in the second round of optional examinations in order to improve their possibilities of qualifying for their chosen major.

\begin{tabular}{|c|c|r|r|}
\hline Variable & Sub-category & Number & Percentage \\
\hline General university & 5 to 6 & 76 & $22.1 \%$ \\
\cline { 2 - 4 } entrance examination & 6.1 to 8 & 166 & $48.3 \%$ \\
\cline { 2 - 4 } scores & 8.1 to 10 & 57 & $16.6 \%$ \\
\hline
\end{tabular}

Table 4. General university entrance examination scores obtained by sample population

We sought to determine whether there were substantial differences between the university entrance examination scores achieved by students who had studied in public schools and by those who had attended private schools. Application of Levene's test for equality of variances confirmed that students who studied in public schools achieved higher test scores than their counterparts who studied at private schools, regardless of whether those schools had a religious affiliation.

The study also confirmed that tuition and expenses related to a university education are overwhelmingly borne by students' families (73.3\%). Table 5 illustrates the distribution of other financial aid received by students in the sample group.

\begin{tabular}{|c|c|r|r|}
\hline Variable & Sub-category & Number & Percentage \\
\hline \multirow{3}{*}{$\begin{array}{c}\text { How students' } \\
\text { educational } \\
\text { costs are }\end{array}$} & Costs covered by student's family & 252 & $73.3 \%$ \\
\cline { 2 - 4 } funded & University scholarship & 7 & $2.0 \%$ \\
\cline { 2 - 4 } & Scholarship from autonomous community & 5 & $1.5 \%$ \\
\cline { 2 - 4 } & Scholarship from Ministry of Education & 54 & $15.7 \%$ \\
\cline { 2 - 4 } & Other type of scholarship or financial aid & 5 & $1.5 \%$ \\
\cline { 2 - 4 } & Costs covered by the students themselves & 21 & $6.1 \%$ \\
\hline
\end{tabular}

Table 5. Burden of higher education costs of sample population

Regarding students' choice between private and public universities, the study showed that more students preferred public institutions $(69.8 \%)$ than private institutions (30.2\%). 
The following table shows how students participating in the survey ranked available sources of information on their higher education options.

\begin{tabular}{|c|c|c|c|c|c|c|}
\hline Sources of information & $\begin{array}{l}\text { Ranking } \\
\text { by entire } \\
\text { sample }\end{array}$ & $\begin{array}{l}\text { Ranking } \\
\text { by female } \\
\text { students }\end{array}$ & $\begin{array}{l}\text { Ranking } \\
\text { by male } \\
\text { students }\end{array}$ & $\begin{array}{c}\text { Male } \\
\text { students }\end{array}$ & $\begin{array}{l}\text { Female } \\
\text { students }\end{array}$ & Total \\
\hline University web site & 1 & 1 & 1 & 99 & 222 & 321 \\
\hline $\begin{array}{c}\text { Other publications (Guides, } \\
\text { catalogues) }\end{array}$ & 2 & 2 & 4 & 65 & 170 & 235 \\
\hline Family & 3 & 3 & 3 & 67 & 158 & 225 \\
\hline University students & 4 & 4 & 2 & 68 & 149 & 217 \\
\hline schoolmates & 5 & 5 & 5 & 63 & 139 & 202 \\
\hline Site visit to the university & 6 & 6 & 7 & 60 & 137 & 197 \\
\hline Other friends & 7 & 7 & 6 & 62 & 130 & 192 \\
\hline Family friends & 8 & 8 & 8 & 55 & 122 & 177 \\
\hline Educational fairs & 9 & 9 & 13 & 40 & 121 & 161 \\
\hline $\begin{array}{l}\text { Information provided by } \\
\text { teachers and guidance } \\
\text { counsellors at school }\end{array}$ & 10 & 10 & 9 & 49 & 111 & 160 \\
\hline $\begin{array}{l}\text { University presentations } \\
\text { made at secondary schools }\end{array}$ & 11 & 11 & 12 & 44 & 108 & 152 \\
\hline University alumni & 12 & 12 & 10 & 47 & 96 & 143 \\
\hline Other web sites & 13 & 14 & 11 & 45 & 86 & 131 \\
\hline Social networks & 14 & 13 & 14 & 37 & 87 & 124 \\
\hline Advertising in other media & 15 & 16 & 15 & 31 & 79 & 110 \\
\hline $\begin{array}{c}\text { University open house } \\
\text { events }\end{array}$ & 16 & 15 & 17 & 28 & 82 & 110 \\
\hline $\begin{array}{l}\text { Audiovisual presentations } \\
\text { (institutional videos, etc.) }\end{array}$ & 17 & 17 & 16 & 30 & 69 & 99 \\
\hline $\begin{array}{c}\text { Information Centers Public } \\
\text { Administration }\end{array}$ & 18 & 18 & 19 & 20 & 53 & 73 \\
\hline Press advertising & 19 & 19 & 18 & 23 & 32 & 55 \\
\hline Television advertising & 20 & 20 & 20 & 8 & 20 & 28 \\
\hline Radio advertising & 21 & 21 & 21 & 8 & 19 & 27 \\
\hline
\end{tabular}

Table 6. Ranking of information sources used by sample population to make higher education choices

Survey results indicated that students considered university websites to be their top source for information on higher education options, confirming findings on youth media consumption published in other reports (Barlovento Comunicación, 2010; GECA Consultores, 2011) that stress young peoples' preference for Internet over more traditional media such as radio, television, the press, or motion pictures. They ranked catalogues and brochures in second place. Family members, alumni, and friends ranked third, fourth, and fifth in importance.

Respondents were also asked to rank the relative weight of factors that influenced their choices of degree programmes and universities (see table 7).

Students ranked the quality of a university's teaching, its reputation, and the practicality of a degree as being the three factors that most swayed their decisions concerning what degree they should earn and where they should study, closely followed by a university's international projection. They showed mature judgement 
in weighing the many academic, career, logistical, and economic factors they needed to consider.

\begin{tabular}{|c|c|c|c|}
\hline Choice criteria and factors (ranked on a scale of 1 to 5 ) & Mean & Standard dev. & Ranking \\
\hline Teaching quality & 4.01 & 1.027 & 1 \\
\hline University's reputation & 3.83 & 1.093 & 2 \\
\hline Practicality of degree offered & 3.61 & 1.087 & 3 \\
\hline University's international projection & 3.57 & 1.148 & 4 \\
\hline Variety of degrees offered & 3.52 & 1.25 & 5 \\
\hline University's level of technology & 3. 1 & 1.222 & 6 \\
\hline Appealing curriculum & 3.49 & 1.159 & 7 \\
\hline Test score required for admission & 3.44 & 1.239 & 8 \\
\hline Appealing facilities & 3.35 & 1.264 & 9 \\
\hline Public transport options & 3.28 & 1.338 & 10 \\
\hline Appealing academic activities & 3.25 & 1.08 & 11 \\
\hline University website & 3.2 & 1.206 & 12 \\
\hline Annual costs & 3.15 & 1.375 & 13 \\
\hline Friendliness of university personnel & 3.15 & 1.181 & 14 \\
\hline Institution's humanist approach & 3.12 & 1.095 & 15 \\
\hline Efficacy of university job bank & 3.07 & 1.236 & 16 \\
\hline Student/teacher ratios & 3.02 & 1.278 & 17 \\
\hline Recommendation of current students & 2.99 & 1.277 & 18 \\
\hline Quality of guidance and student assistance services & 2.98 & 1.148 & 19 \\
\hline Professors' research reputation & 2.93 & 1.122 & 20 \\
\hline Proximity to place of residence & 2.93 & 1.526 & 21 \\
\hline Nearest university that offered desired degree programme & 2.88 & 1.584 & 22 \\
\hline Friends' recommendations & 2.88 & 1.203 & 23 \\
\hline Family recommendations & 2.85 & 1.255 & 24 \\
\hline Personal attention and tutoring & 2.85 & 1.185 & 25 \\
\hline English language curriculum and activities & 2.79 & 1.222 & 26 \\
\hline Direct marketing and contact (site visits, mailings) & 2.62 & 1.135 & 27 \\
\hline Possibility of studying away from home & 2.59 & 1.465 & 28 \\
\hline University's media presence & 2.55 & 1.199 & 29 \\
\hline Difficulty in entering a public university & 2.54 & 1.518 & 30 \\
\hline Sports activities & 2.38 & 1.231 & 31 \\
\hline Difficulty in entering a private university & 2.21 & 1.394 & 32 \\
\hline
\end{tabular}

Table 7. Factors that influenced the higher education decisions of students surveyed

Regarding who made the final decisions concerning what and where they would study, $65.4 \%$ of the students surveyed stated that they alone had been responsible for their decisions and another $21.2 \%$ stated that they had made their decision after consulting with their parents (see table 8 ).

\begin{tabular}{|c|c|r|r|}
\hline Variable & Sub-category & Number & Percentage \\
\hline \multirow{4}{*}{$\begin{array}{c}\text { Who made the } \\
\text { decision what and } \\
\text { where the student } \\
\text { would study }\end{array}$} & Students who decided on their own & 225 & $65.4 \%$ \\
\cline { 2 - 4 } & $\begin{array}{c}\text { Students who decided after consulting } \\
\text { their parents }\end{array}$ & 73 & $21.2 \%$ \\
\cline { 2 - 4 } & $\begin{array}{c}\text { Students who decided jointly with their } \\
\text { parents }\end{array}$ & 30 & $8.7 \%$ \\
\cline { 2 - 4 } & $\begin{array}{c}\text { Students whose parents made the } \\
\text { decision after considering their opinion }\end{array}$ & 2 & $0.6 \%$ \\
\cline { 2 - 4 } & $\begin{array}{c}\text { Students whose parents made the } \\
\text { decision for them }\end{array}$ & 1 & $0.3 \%$ \\
\cline { 2 - 4 } & No opinion/no response & 4 & $1.2 \%$ \\
\hline
\end{tabular}

Table 8. Who made decisions regarding the higher education of students surveyed

We asked respondents if their friends or family members had studied or were presently studying communication sciences in order to know if this might have been 
a factor influencing their decision to choose this degree and found that although they had few family references (only $18 \%$ reported family members who had studied communication), almost half had friends who had chosen this major (see table 9). This observation points to need for further research concerning the influence friends exert on a student's decision to pursue a specific degree.

\begin{tabular}{|c|c|c|}
\hline \multicolumn{3}{|c|}{$\begin{array}{l}\text { Question: Has any member of your family studied or is } \\
\text { currently studying for a degree in communication sciences? }\end{array}$} \\
\hline Reply & Number & Percentage \\
\hline Yes & 62 & $18.0 \%$ \\
\hline No & 273 & $79.4 \%$ \\
\hline \multicolumn{2}{|c|}{ Question: Have any of your friends studied or are currently } \\
studying for a degree in communication sciences?
\end{tabular}

Table 9. History of communications studies among friends and family of survey group

\section{Conclusions}

The results of the study confirmed our first hypothesis that the primary factors determining a future communications sciences student's choice of a university were the quality of its teaching and its excellence and reputation.(5)

In this sense, we are in line with the results of studies done $y$ the researchers Soutar and Turner (2002), Maringe (2006), and Holsworth and Nind (2005), work in which the factors of reputation, excellence, and quality of teaching staff were vital in for students who were choosing a University.

Our second hypothesis, that communication sciences students placed the highest value on direct and experiential sources, was also confirmed. Survey respondents stressed the importance of site visits, higher education fairs, and the direct input of friends and family members, and also stated their preference for using virtual tools such as Internet search, university websites, and social networks to research their options.

The study also provided empirical evidence confirming our third hypothesis that Spanish students preferred to study communication sciences at public universities rather than private universities.

Other conclusions from this study that have significant ramifications for university marketing and student recruitment in Spain include:

- Higher education marketing is a consolidated field of marketing that universities can use to develop more effective recruitment strategies and 
nurture students' feelings of identification so that as graduates they will gladly promote their alma maters and their programmes.

- Of the communication sciences students surveyed for this study, those who received their secondary education in public schools scored higher on university entrance examinations than their colleagues who attended private secondary schools.

- A high percentage of the university communication sciences students who responded to the study survey indicated that they had made their own decisions concerning the degree they would study and the university they would attend. Furthermore, their responses concerning how they reached their decisions demonstrated their maturity and their preparedness for making an important life decision.

\section{Future lines of research}

This study has shown how reputation, excellence, and perceived quality are determining factors for choosing a University. Accordingly, the Communication and Marketing departments of Universities (public and private) work hard to project those attributes in all the communication that they produce. In future research, it will of interest to go deeper into how Universities project those intangibles onto various communication supports, and what are the intangible aspects upon which Universities rely to position those intangibles with future students. Another aspect of interest for future approaches to the subject would be to determine the extent to which the cost of registration has an effect on the Choice of a public or private University.

\section{References}

ALIFF, J.V. (1998). Are students "customers" of collegiate education?. Annual General Meeting of the Georgia Academy of Science, 25 April, 1-10.

BALDWIN, G. (1994). The student as customer: the discourse of "quality" in higher education. Journal of Tertiary Education Administration, 16(1): 125-133.

BARLOVENTO COMUNICACIÓN (2010). Informe sobre las audiencias. http://tinyurl.com/76m3rcl - Accessed 10 May 2011. 
BEERLI, A.; DÍAZ, G. (2003). Los efectos de la imagen percibida de la universidad en la satisfacción de los estudiantes. Revista Española de Investigación de Marketing, ESIC, 7(1): 7-25.

CHAPMAN, R. (1986). Towards a theory of college selection: A model of college search and choice behaviour. Advances in Consumer Research, 13. Association for Consumer Research, Provo, Utah.

CHEN, W.W. (2009). Hospitality and tourism management education: An analysis of Chinese undergraduate students' motives and institution choice criteria. http://tinyurl.com/6649zy5 Accessed 10 May 2011.

CHRISTOPHER, M.; PAYNE, A.; BALLANTYNE, D. (1991). Relationship Marketing. Butterworth-Heinemann.

COMM, C.L.; LABAY, D.G. (1996). Repositioning Colleges Using Changing Student Quality Perceptions: An Exploratory Analysis. Journal of Marketing for Higher Education, 7(4): 21-35. http://dx.doi.org/10.1300/J050v07n04 02

DAVIES, P.; SCRIBBINS, K. (1985). Marketing Further and Higher Education. Longman Group Ltd.

DECLARATION OF THE EUROPEAN MINISTERS OF EDUCATION CONVENED IN BOLOGNA (1999). http://tinyurl.com/6seums2 - Accessed 2 May 2011.

DEL OLMO ARRIAGA, J.L. (2009a). Els factors d'elecció d'Universitat: El cas de la demanda a Catalunya. [Doctoral thesis]. Universitat Abat Oliba CEU, Barcelona, Spain.

DEL OLMO ARRIAGA, J.L. (2009b). La elección de Universidad: factores de decisión y canales de información. Editorial CEU Ediciones.

DELMONICO, M.J. (2000). Is Treating Students as Customers the Right Move for Community Colleges?. St Petersburg Junior College, St Petersburg, FL, 1-16.

DRISCOLL, C.; WICKS, D. (1998). The Customer-Driven Approach in Business Education: a Possible Danger?. Journal of Education for Business, 74(1): 58-61. http://dx.doi.org/10.1080/08832329809601663

EUROPEAN COMMISSION COM (2002). European benchmarks in education and training: follow-up to the Lisbon European Council. The Commission of the European Communities, Brussels. 20-11-02. 
EUROPEAN COMMISSION COM (2003). The role of universities in "the Europe of Knowledge". The Commission of the European Communities, Brussels. 05-02-03.

EUROPEAN HIGHER EDUCATION AREA (EHEA). Available online in: http://tinyurl.com/89hxk39. Accessed 15 May 2011.

FUNDACIÓN CYD (Conocimiento Y Desarrollo) (2009). Informe de la Fundación Conocimiento y Desarrollo 2009. http://tinyurl.com/6hg6309 - Accessed 2 May 2011.

GECA CONSULTORES (2011). Informe sobre el consumo de la Televisión. http://tinyurl.com/6s6llpn - Accessed 2 May 2011.

GRÖNROOS, C. (1994). From marketing mix to relationship marketing: Towards a paradigm shift in marketing. Management Decisions, 32(2): 4-20. http://dx.doi.org/10.1108/00251749410054774

HELGESEN, O. (2008). Marketing for higher education: A relationship marketing approach. Journal of Marketing for Higher Education, 18(1): 50-78. http://dx.doi.org/10.1080/08841240802100188

HOLSWORTH, D.W.; NIND, D. (2005). Choice modelling New Zealand high school seniors' preferences for university education. Journal of Marketing for Higher Education, 15(2): 81-104.

INFORME ANUAL DE LA PROFESIÓN PERIODÍSTICA (2010). Ed. Asociación de la Prensa de Madrid.

KEEN, C.; WARNER, D. (1989). Visual \& Corporate Identity: A Study of Identity Programmemes in the College. Polytechnic and University Environment, Heist Publications.

KOTLER, P.; FOX, K.A. (1995). Strategic Marketing for Educational Institutions (2nd Eds.). Prentice Hall.

LANDRUM, R.E.; TURRISI, R.; HARLESS, C (1998). University image: the benefits of assessment and modelling. Journal of Marketing for Higher Education, 9(1): 5368. http://dx.doi.org/10.1300/J050v09n01 05

LUQUE, T.; DEL BARRIO, S. (2007). Análisis del valor de las percepciones de los clientes en el diagnóstico estratégico de la universidad. International Congress of Marketing Trends, 26-27 January 2007. 
LUST, P. (1998). Students as Customers: Would you like fries with your Shakespeare?. Osborn, R.E.E. (Eds.), Scholarship, Service, and Integrity: Benchmarks in a Changing Landscape, ACHE Proceedings, Pennsylvania, 54.

MARINGE, F. (2006). University \& Course Choice: Implications for positioning, recruitment and marketing. International Journal of Educational Management, 20(6): 466-479. http://dx.doi.org/10.1108/09513540610683711

MINISTERIO DE EDUCACIÓN (2010). Estrategia Universidad 2015. Servicio De publicaciones del Ministerio de Educación. http://tinyurl.com/6kmcdau

OFICINA DE COOPERACIÓN UNIVERSITARIA (OCU) (2010). 2020 Tendencias Universidad: estudio de prospectiva. http://tinyurl.com/3zy48tz - Accessed 20 May 2011.

PITMAN, T. (2000). Perceptions of academics and students as customers: A survey of administrative staff in higher education. Journal of Higher Education Policy and Management, 22(2): 165-75. http://dx.doi.org/10.1080/713678138

SEYMOUR, D.; COLLETT, C. (1991). Total Quality Management in Higher Education: A Critical Assessment. GOAL/QPC, Methuen, MA.

SHUPE, D.A. (1999). Productivity, quality, and accountability in higher education. Journal of Continuing Higher Education, 47(1): 2-13. http://dx.doi.org/10.1080/07377366.1999.10400360

SOUTAR, G.N.; TURNER, J.P. (2002). Students' preferences for university: A conjoint analysis. International Journal of Educational Management, 16(1): 40-45. http://dx.doi.org/10.1108/09513540210415523

TIERNEY, W.G. (1999). Building the Responsive Campus: Creating High Performance Colleges and Universities. Sage Publications, Thousand Oaks, CA.

TRULLAS, I.; ENACHE, M. (2011). Anàlisi teòrica dels antecedents i conseqüències de la identificació de l'alumnat amb la universitat i de la seva percepció de qualitat universitària. Intangible Capital, 7(1): 170-212. http://tinyurl.com/69sfeub Accessed 30 April 2011. http://dx.doi.org/10.3926/ic.2011.v7n1.p170-212

VELOUTSOU, C.; LEWIS, J.W.; PATON, R.A. (2004). University selection: Information requirements and importance. International Journal of Educational Management, 18(3): 160-171. http://dx.doi.org/10.1108/09513540410527158 
Due to the length of the questionnaire, this was not included in the article. For to consult, please contact directly with the author.

Intangible Capital, 2012 (www.intangiblecapital.org)

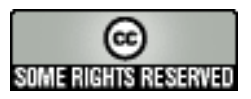

Article's contents are provided on a Attribution-Non Commercial 3.0 Creative commons license. Readers are allowed to copy, distribute and communicate article's contents, provided the author's and Intangible Capital journal's names are included. It must not be used for commercial purposes. To see the complete licence contents, please visit http://creativecommons.org/licenses/by-nc/3.0/es/ 